\title{
Analysis of pelvic motion during gait with bivalve brace
}

\author{
Lydie Journoud $^{1 *}$, Julie Deceuninck², Jean-Claude Bernard² ${ }^{2}$ Cyril Lecante $^{1}$ \\ From 11th International Conference on Conservative Management of Spinal Deformities - SOSORT 2014 \\ Annual Meeting \\ Wiesbaden, Germany. 8-10 May 2014
}

\section{Background}

In the literature many articles explain that it is essential to have a femoral brace to restricted pelvic motion during gait. However, two principles to restrict the movement of the trunk in a brace: contention (hydraulic structure of the trunk) and the balance of power (three points system). But we are unable to know how much.

\section{Aim}

The aim of this study is pelvis moves into the thoraco lumbar brace during gait, compared to a gait without the brace.

\section{Materials and methods}

2 asymptomatic adults, with similar physical feature.

They wear a thoracolumbar bivalve brace, made with the same protocol (using CAD CAM) for reproducibility. We design the braces according to the principles of the brace immobilization:

- a good grip on the waist and overall tightening

- supports on the abdomen, thorax and lumbar.

We use the gait analysis system Vicon ${ }^{\circledR}$. To use this system, we make holes in the brace at the location of the markers. Each person walks 6-8 trials in the gait analysis system with and without the brace.

\section{Results}

The kinematic curves of the pelvic motion compared to the laboratory standard show that there is a significant decrease in the movement of the pelvis. With the brace, the range of motion is negligible.

\section{Conclusion}

This preliminary experimentation allowed us to see that we could use the gait analysis system to evaluate the efficiency of brace. In a second step we have to consider a study on the patients who wear their braces on a longer time. So we will be able to objectify the efficiency of immobilization of the pelvis in a brace.

\section{Authors' details}

${ }^{1}$ Lecante SA, Lyon, France. ${ }^{2}$ CMCR des Massues, Lyon, France.

Published: 4 December 2014

doi:10.1186/1748-7161-9-S1-O50

Cite this article as: Journoud et al:: Analysis of pelvic motion during gait with bivalve brace. Scoliosis 2014 9(Suppl 1):O50.
Submit your next manuscript to BioMed Central and take full advantage of:

- Convenient online submission

- Thorough peer review

- No space constraints or color figure charges

- Immediate publication on acceptance

- Inclusion in PubMed, CAS, Scopus and Google Scholar

- Research which is freely available for redistribution
C Bïomed Central 